\title{
Lost in Translation? Latin American Lawyers-Students in American Law Schools: Transplants and Globalization
}

\author{
Rogelio PéreZ-PeRdomo*
}

Pérez-Perdomo, R., 2019. Lost in Translation? Latin American Lawyers-Students in American Law Schools: Transplants and Globalization. Received 10 December 2018, Accepted 03 September 2019. Oñati Socio-Legal Series [online], 9(6), 1078-1096. Available from: https://doi.org/10.35295/osls.iisl/0000-0000-0000-1082

\begin{abstract}
In the 1960s, law graduates from Latin American and other civil law countries started flocking to American law schools. Comparative law scholars have discussed the wide differences between American and civil law systems of legal education and predicted trials and tribulations for students going to the United States. This article argues that such students do not experience the predicted shock mainly because American law schools have undergone major changes themselves and legal education in civil law countries has also changed. These changes are part of globalization. The article also speculates about other possible consequences of the globalization of legal education.
\end{abstract}

\section{Key words}

Legal education in the U.S.; Latin American legal education; globalization of law

\section{Resumen}

En la década de 1960 graduados en derecho de América Latina y de otros países de tradición romanista comenzaron a frecuentar las escuelas de derecho de los Estados Unidos. Los comparatistas predijeron graves dificultades de adaptación por las diferencias en la concepción del derecho y en la educación jurídica. El artículo sostiene que la adaptación ha sido más fácil de lo esperado tanto por las transformaciones de las escuelas de derecho de los Estados Unidos como los cambios en la educación jurídica en los países romanistas. Esto es parte de la globalización

\footnotetext{
* Studies of law at Universidad Central de Venezuela (1959-64), philosophy and sociology of law at Paris (1964-66) and Harvard (1971-72). L1M (Harvard, 1972) and Dr. Ciencias/Derecho (SJD), Universidad Central de Venezuela, 1976. Professor of law and former dean, Universidad Metropolitana, Caracas. Frequent Visiting Professor at Stanford Law School since 1998. Professor at Universidad Central de Venezuela (1967-1988) and Instituto de Estudios Superiores de Administración (1988-1998). Visiting Fellow at the Institute of Development Studies, Sussex (1977), Visiting Professor at University of the Basque Country (1991-1992), CIDE and Instituto de Investigaciones Jurídicas of UNAM, Mexico (2010). Florida International University College of Law, 2012. Academic Director of Stanford Program for International Legal Studies (1999-2001), Scientific Director of Oñati International Institute for the Sociology of Law (1991-92). President of the Research Committee on Sociology of Law, International Sociological Association (1992-1995). International Scholarship Prize. Law and Society Association. 2011. Premio a la Investigación y Creación Intelectual. Universidad Metropolitana, 2005-2006. Many academic publications. The most recent books are Justicia e injusticias en Venezuela (Academia de la Historia and Universidad Metropolitana, 2011) and Law in many societies (co-editors: Lawrence Friedman and Manuel Gómez, Stanford University Press, 2011). Present research lines: legal scholarship and legal culture. Contact details: Stanford Law School. Crown Quadrangle, 559 Nathan Abbott Way. Stanford, CA 943058610. Email address: rperez3@law.stanford.edu
} 
de la educación jurídica. El artículo examina otras consecuencias posibles de la globalización.

\section{Palabras clave}

Educación jurídica en EE. UU.; educación jurídica latinoamericana; globalización del derecho 


\section{Table of contents / Índice}

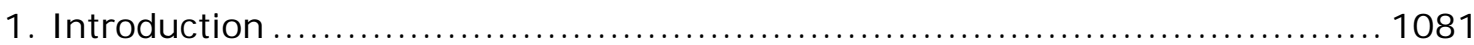

2. What does a leading American law school offer? ............................ 1083

2.1. American and Latin American legal education compared ................... 1083

2.2. Stanford Law School: past and present offerings...................... 1086

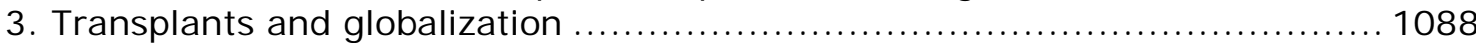

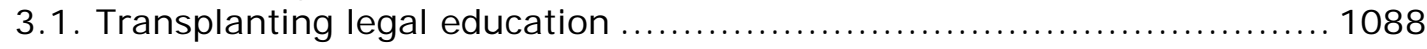

3.2. Will globalization change legal education and make top American law schools less attractive? ............................................................ 1090

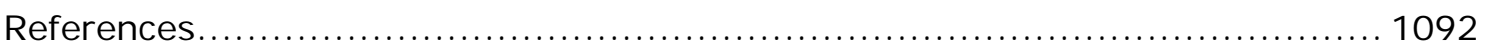




\section{I ntroduction}

In 1968 a distinguished comparative law scholar published a reflective article on the major differences between American and European legal education (Damaska 1968). This was at a time when people from countries educated in the civil law tradition began attending American law schools. The purpose of the article was to explain how the law schools in Europe shaped the mind of lawyers in a certain way and the difficulties that could be expected with regard to understanding the way law was taught in the United States. Damaska's title was well chosen: "A continental lawyer in an American law school: trials and tribulations of adjustment". Trials and tribulations were to be expected.

Damaska ended his article by discussing how to facilitate the adjustments of civil law lawyers to the American law school. He saw the need for some type of translation, but It was not a question of language but of mentality. The civil lawyers were educated in a certain approach to the law, and American law schools had a quite different approach. John Henry Merryman (1974), another great name in comparative law, basically agreed with Damaska on the existence of a gap between the education of lawyers in the civil law tradition and in the U.S. He did not explicitly discuss the difficulties in the adaptation between these distinctive legal traditions, but the reader can infer that these two major comparative scholars perceived the need for a process to facilitate better communication between lawyers educate in them. In a nod to Sofia Coppola's film (2003), we can say that lawyers educated in the civil law tradition could be expected to be lost in translation in American law schools.

Fifty years have elapsed since the publication of these articles. American law schools have become very attractive to civil law lawyers from all over the world. Thousands of lawyers from Europe, Asia, Africa, and Latin America, mostly from civil law countries, now come to the United States every year in search of opportunities to supplement their legal education. Damaska wrote when this movement was just beginning, in the late 1960s. This article argues that the tribulations have probably been less severe than Damaska expected and will try to explain why. Other scholars believe that the gap still persists (Lazarus-Black 2017). These different perceptions are part of the research problem.

Beyond its attraction to foreign lawyers, American legal education also has become a kind of model or inspiration for the reform of legal education in other parts of the world. In the mid 1950s, Latin American law professors started looking at American law schools and their approach to legal education (Pérez-Perdomo 2006). In the late 1960s American law professors tried to spread the gospel of the case method and Socratic style of teaching law throughout Latin America, but the effort was soon declared a failure (Trubek and Galanter 1974). New research has revisited the issue and concluded that the interactions between American universities and Latin American law schools were more extended and produced more lasting consequences than earlier thought (Dezalay and Garth 2002). These efforts were not completely unrelated to the attraction of American law schools. Last, but not least, the model of American law firms has expanded worldwide, and it is possible to ask if the attraction of American legal education has a relation to these changes in the legal profession worldwide, and particularly in Latin America (Gómez and Pérez Perdomo 2018).

One of the difficulties of this topic is that legal education is a complex world in itself, and law schools are only one part of it. It is increasingly difficult to talk about American, European or Latin American legal education. Even if the subject is reduced to the contribution of the law school to legal education, there are significant national variations, and even the variations from one school to another within a nation can be very significant. In the United States these variations are substantial, but this is also true for other countries. In Mexico, for example, Pérez Hurtado (2009) distinguishes three radically different types of law schools. Even if we select what are generally considered top law schools in a particular country, the differences in approaches, 
methods and contents are very apparent, as in the case of Venezuela (Pérez Perdomo 2018b).

This article tries to avoid this difficulty by concentrating the description and reflection on one American law school, Stanford, and analyzing what it has offered and what is appreciated by foreign lawyers, particularly the ones from Latin America. This was the law school Merryman had in mind when he made his comparative study. The questions that guide the article are: What do the law graduates from abroad who come to study at a top law school in the United States expect and find there? Why do these lawyers come to an American law school? And what are the difficulties in adapting to it? In addition, this article discusses the reverse problem: whether legal education can be transplanted, and in particular whether American legal education can be transplanted to Latin America. The argument here is that the two issues are related.

An element that Damaska and Merryman could not have foreseen in the 60 s and $70 \mathrm{~s}$ is the social, economic, political and technological change that have occurred in the world. The term 'globalization' helps to capture these changes: people from different countries and cultures of the world have far more contacts among themselves, they know more than in the past about each other and about ideas and ways of doing things in different countries. In addition, behavior patterns have spread worldwide more intensively than before. Institutions have become more international.

The law is not immune to these changes. Multinational law firms are now common; the practice of law has become more international or more global. This is relevant because law firms obviously play an important role in legal education. Big law firms are the premier employers of those who graduate from the law schools in the United States. In addition, a number of Latin American law students who come to United States have practiced law in these international law firms or in international organizations.

Law schools in Latin America and other parts of the civil law tradition are increasingly offering courses in comparative law or in matters such as international commerce, international negotiations, international human rights. Even areas of law traditionally considered domestic, like family law or labor and employment law, now have an international dimension. A European or a Latin American lawyer who comes to the United States today most likely has more information on what she will find in America, both in relation to the law and the legal education, than the European or Latin American lawyer of 1970 had.

For this article, I naturally rely on the existing literature on this topic and other documentary sources, but much of the information is drawn from my personal observation of the life at Harvard Law School in the early 70s, where I was a Master's student and later a visiting scholar and at Stanford Law School during the last twenty years where I have been a visiting professor during the fall quarter. I am aware of the limits, dangers and possibilities of autoethnography (Adams et al. 2015, Campbell 2016, Wall 2016). For this reason, the article also uses documentary sources and interviews and informal discussions with Latin American lawyers who have come for masters- and doctoral-level studies at Stanford and with Stanford law faculty members who have lived through the changes at this law school over the last decades.

The first topic this article will discuss is what a top American law school offers to foreign students and how the "trials and tribulations of adjustment" are experienced or avoided. The second issue is whether transplants of educational models and globalization impact on students and professors. We finish by asking if the convergence of legal education can remove the incentive to travel to a foreign country in search of further legal education. 


\section{What does a leading American law school offer?}

\subsection{American and Latin American legal education compared}

Merryman (1974) conducted a now classical study comparing law schools in the United States and the civil law tradition. Instead of primarily comparing the conceptions of law and the teaching approaches, Merryman observed the law schools with a sociological eye. He looked at the people - the students and the professors and the organization and processes. He was acutely aware of differences in legal education even within the same country. For his analysis of American legal education, he used the leading law schools of his time, and particularly Stanford, where he taught for many years. Regarding the civil law tradition, he signaled his familiarity with the Italian and Chilean law schools of that time, while acknowledging that Chilean legal education was in the process of change (Merryman 1974, note 7). At that time, European and Latin American law schools were less stratified than those in the United States, and thus the model described by Merryman was basically the same for many law schools in the civil law tradition.

According to Merryman, leading American law schools were meritocratic, competed for the best students and selected a relatively small group of the students each year. Students were already university graduates, and they were four or five years older than law students in the civil law countries. The law schools also competed to hire the most qualified professors and provided good libraries, technical facilities and other services. In general terms, Merryman's description is still accurate with two provisos: leading law schools in the United States are relatively few in number, ${ }^{1}$ while many American law schools lack the resources to follow these leading institutions or to attract the most qualified students or professors.

The second proviso is that the legal education model has been transformed over time. There are geological strata discernible in the American law curriculum (Gordon 2007), and most American law schools of today are quite different places than the same schools in 1960 or 1970 . When Merryman wrote his article, the model itself, as practiced by Harvard, Yale, and other top law schools (Stevens 1983), was attacked for its authoritarianism and cruelty towards the students (Kennedy 1971). Two popular novels brought these criticisms of the model to the attention of the general public (Osborn 1971, Turow 1977).

Merryman had in mind Stanford Law School, which had followed a different path than Harvard and Yale. It welcomed faculty who were close to the so-called "legal realism", "law and society", "law and economics", and "critical studies movement", and also had embarked on curricular innovations and cultivation of a more open attitude towards students (Faculty's interviews 1, 2, 4 \& 5; Méndez 2008, Babcock 2015). But innovation was not confined to Stanford. The 1970s were a period of intense discussion on legal education, changes in teaching methodologies and subjects, as well as changes in the law schools themselves and their programs.

We can call some of these changes internal. The diffusion of new ideas about law and legal education, mostly the products of the sociological jurisprudence, legal realism, law and society, and the critical legal studies movements, had an influence on legal literature, including the casebooks, and on law teaching (Gordon 1989). As Merryman (1974, 871) explained, casebooks were no longer a collection of judicial decisions; they frequently included social science material, or even excerpts from journalism, which shed light on the social and economic context of the court cases or the black letter law (also Faculty's interviews $4 \& 7$ ). Although this would have been disorienting for a Latin American law graduate from a traditional school in 1970, it

\footnotetext{
${ }^{1}$ There are about 200 ABA approved law schools in the United States and a number of non-ABA approved. The most widely known (and criticized) ranking is published yearly by a company called the US News and World Report. Attention is highly concentrated on the first ten or twenty "best law schools", according to this publication. In recent years Stanford has frequently occupied the second place behind Yale.
} 
would have been more comprehensible than the Langdellian-style casebook ${ }^{2}$ that Damaska probably had in mind when he wrote his article. For several years now, American law schools have offered courses designed to provide a context for legal studies, including legal history or comparative law, to train in the use of social sciences methods to study law, or to teach advocacy and skills useful for lawyers, such as negotiation and mediation. These courses do not offer any more difficulty to foreign lawyers than to American students. In some cases, Latin American lawyers are better prepared to deal with these courses, for example, when they deal with comparative law or when the Latin American student has had a previous experience as a practicing lawyer (Alumnus' interview 4 ). ${ }^{3}$

Particularly visible during the 1970s were the structural changes in American legal education motivated in part by an interest in receiving foreign graduates in law. During the last three decades, American law schools have offered an increased number of Master in Law (LL.M.) and Scientia Juris Doctor (S.J.D.) programs designed mostly for foreign students; this is true not only for elite American law schools but across the broad spectrum of law schools. For example, in 1971, Harvard had three programs of post-graduate education that admitted foreigners: The International Tax Program, the Master in Law and the Scientia Juris Doctor. At that time only the master and doctoral programs were considered academic, but the tax program was later converted into a concentration of the masters' program. ${ }^{4}$ New York University and other universities also offered LL.Ms and S.J.Ds programs more or less geared toward graduates from the civil law countries. By 2004, 100 law schools offered 209 master programs. This was out of a total of 183 law schools approved by the American Bar Association at that time (Vides et al. 2011, 365). A few years later the number had increased to 114 law schools (Silver 2012, 2387). Thousands of foreign law graduates, including many from Latin America, have enrolled in these programs each year. In 2016, the American Bar Association reported 9,866 post-J.D. students, most of them from foreign countries, and 3 percent of J.D. students are foreigners (Silver and Ballakrishnen 2018, 50 and note 48. Also Ballakrishnen and Silver 2019). ${ }^{5}$ There is even a literature to help foreign law graduates choose an American master program (Edwards 2011).

The credits required for graduation could be obtained not only in the law school but also in other departments. The structure was simple: the foreign students had to take a short course on Introduction to American Law and then were more or less free to select a number of courses related to their interests. They usually prefer the second- and third-year courses, which are more specialized, and avoid the first year where the traditional type of teaching is more anchored. If the foreign student-lawyer wants to pass a bar examination in the United States her choices are more limited.

We can imagine a European or Latin American law graduate arriving at an oldfashioned American law school, one with the classic three-year J.D. program, centered on American law, and where the bulk of the class discussions were about American judicial decisions. It is easy to see that such a student would have experienced what we can call the Damaska shock: they would need a completely new "chip" implanted in their brain to understand what it was all about. But from the 1970s on, the situation was at least somewhat different. The LL.M. and S.J.D.

\footnotetext{
2 This was my personal experience as a LL.M. student at Harvard Law School in 1971. The book of Hart and Sacks (1958) on legal process used by then assistant professor David Kennedy was surprising but comprehensible, and the class was friendly, while the class on contracts I audited was baffling and very much in the Langdellian style.

${ }^{3}$ Law school, particularly the J.D. program is still a challenging experience for students, in general (McClurg 2012, 2017).

4 In 2018-19 the master program received 188 students (98 foreigners) See: https://hls. harvard.edu/dept/graduate-program.

${ }^{5}$ For context and a fuller appreciation of the importance of foreigners in American law schools, we can note that the total enrollment in law schools is about 40,000 yearly from 2011 to 2018. See https://data. lawschooltransparency.com/enrollment/all/\#
} 
programs were flexible enough for foreigners to adapt them to their interests. ${ }^{6}$ This is one of the reasons why foreign students in recent decades were unlikely to have received the terrible shock that Damaska envisioned.

For Latin American lawyers, there is a third reason for an easier-than-expected adaptation to American law schools. Legal education in Latin American has also changed during this period. Interest in the case method and the interdisciplinary approach started in the 1950s and was a standard recommendation for change in the conferences of law deans of the 1960s (Pérez-Perdomo 2006, 108ff). When the law and development missionaries arrived from the United States in the 1960s, they found allies. When they left a few years later, Latin American law professors who were advocates for change in legal education kept working. In the last decades of the $20^{\text {th }}$ century a good number of private universities with law schools were founded, and the number of full-time law professors increased significantly (Pérez-Perdomo 2006). The changes in Latin American law schools have partially closed the gap in terms of approaches to legal education and have made American law schools more attractive and more familiar. Traditionally, Latin Americans looked to Europe for further legal studies, but in the final decades of the $20^{\text {th }}$ century, they started looking to the United States.

The attraction of American law schools has an intellectual component. They are supposed to be different from the law school where the young graduate has finished her legal studies but not completely alien for the Latin American and European educated lawyers. They are assumed to be more advanced in promoting an interdisciplinary focus, particularly in the relations between law and business. There are also practical reasons for attending a master's program and completing a year of training in an American law firm. These experiences can be important for those who want to become associated with the international law firms that have been expanding all over the world (Gómez and Pérez Perdomo 2018).

For this paper it is important to underline that cultural shock was not an important aspect of the foreign student experience. In their discussion of the challenges facing foreign students who were studying law in the United States, Vides, Gómez and Pérez Hurtado (2011) did not even mention it. Students were concerned with finance and visa issues, not with the shock of clashing legal cultures.

The observation can be extended to Latin American lawyers who have decided to do a J.D. program ("J.D.s with advanced standing"). ${ }^{7}$ Frequently they are already familiar with American law schools or legal practice, even with the language of American law. Like American students, they may face surprise and anxiety, but probably to a lesser extent than the ordinary 1L student (Mertz 2007, Young 2018, Alumnus' interview 4). The law school of origin likely plays a large role in determining whether the adaptation to the American law school is smoother or more difficult. Of course, for many foreign students, there is also the difficulty of working in English, a foreign language for them, but frequently they are a select group (Alumnus interview $6 \& 7)$. Nowadays the well-traveled and sophisticated foreign student is more common that the traditional provincial student.

Contrary to the picture presented thus far, Lazarus-Black (2017) found that foreign LL.M. students, who are lawyers in their country of origin, reported many surprising and even negative aspects of American culture, particularly American law schools and conceptions of law. The purpose of her article was to give voice to the concerns of these students. Many of these concerns are related to the features of the civil law tradition educational style and conception of law as described by Merryman (1974) and Damaska (1968): teaching methods based on lectures and memorization,

\footnotetext{
${ }^{6}$ When I came to Harvard, I was already a professor at Universidad Central of Venezuela and my main interest was observing and experiencing methods of legal education. I was appalled by the first-year courses that I observed but I felt at ease in the other courses where I was a student.

${ }^{7}$ These are J.D.s programs that are somewhat shorter for persons who hold a law degree from a recognized foreign university.
} 
equation of law and legislation, and the idea that codes and legislation give uncontested clarity to the law. These ideas correspond to the traditional views of law that were common in the civil law tradition of the past and that have been hotly contested in the last decades (Merryman and Pérez-Perdomo 2019). And contestants have shaped a new type of law schools or have changed their own courses and teaching methods.

Differences in the research questions and methodologies may help explain the apparently opposite conclusions of Lazarus-Black ${ }^{8}$ and the present article. Perhaps the teaching methods, types of foreign students, and the approach to law at the schools she studied (which are not "elite" or top-ranking law schools) is an element to consider. A questionnaire that searches for cultural differences is likely to elicit this type of answer. In this article, I would argue that if there is indeed a deep cultural gap that makes foreign students uncomfortable, it would be difficult to understand why so many foreign law graduates are attracted to and succeed in American law schools.

The internationalization of legal studies in the leading American law schools has made them more attractive and more congenial places for foreign students, and conversely, the internationalization and the presence of foreign students has helped to transform American law schools and legal education. Foreign lawyers-students coming from modern type of law schools or with an exposure to the international practice of law are not 'lost in translation'. Now we can put forward the reverse question: whether internationalization and globalization will erase or diminish the distinctiveness of American legal education and will in the end make it less relevant for Latin American (and European) lawyers who are looking for a more modern, relevant, and complete legal education. But first, it is good to take a look at Stanford Law School, as an example of the curriculum and environment of a leading American law school.

\subsection{Stanford Law School: past and present offerings}

The second half of the $20^{\text {th }}$ century was a time of great change for Stanford University. After the end of World War II, when universities reopened or returned to their former state, Stanford Law School still attracted mostly students from California; its ability to attract good students from elsewhere was limited. It focused on the law of California because its goal was to educate lawyers who would practice in the state (Lempert 2003, Manning 2008, Hufstedler et al. 2008, Pérez Perdomo 2018a). It was considered a good regional law school that followed Harvard's lead (Alumnus' interview 1). The post-war dean, Carl Spaeth (1946 to 1962), and his successors embarked on an ambitious project: they brought in highly qualified professors, publicized the school more widely to obtain better students, and built special and well-equipped buildings and a great library. They campaigned for funds to make all these projects a reality. After some initial resistance, ${ }^{9}$ the curriculum became innovative, incorporating legal writing, lawyering, accounting, statistical and economic analysis, negotiation and other courses based on simulation, and initiating legal clinic (Méndez 2008). Merryman (1974, 863) observed that American law professors had an interest in innovative teaching and that law schools frequently incorporated curricular and other innovations. This was particularly true at Stanford in the 1970s (Méndez 2008, 2009, Babcock 2015).

Particularly remarkable has been the insistence on the interdisciplinary analysis of law and the importance of interdisciplinary scholarship. For the past decade, a PhD in another discipline has become a frequent feature among the newly hired faculty at

\footnotetext{
${ }^{8}$ A detailed description of this interesting research in Lazarus-Black and Globokar (2015) with comments from several colleagues.

${ }^{9}$ During Carl B. Spaeth deanship there were two groups who fought for control of the orientation of the school. Merryman (2007), in his recollections for the oral history project, labeled the groups as the "old guard" and the "young Turks", and he identified those who were the "young Turks" (himself included).
} 
the Law School (Faculty's interview 5). ${ }^{10}$ The production of substantial pieces of scholarship published in top law journals or publishing houses is required for attaining tenure.

Stanford has since become one of the leading law schools, attracting students from all over the United States. Initially, the effort was concentrated on the J.D. program, that is, on the education of lawyers who will practice in the United States. There was also an effort at promoting diversity among the students and faculty. In 1968, Stanford Law School graduated its first African-American student and in the decade of 1970 the school hired the first woman, the first African-American and the first Mexican-American professors (Méndez 2009, Babcock 2013).

In parallel fashion, there was a project of internationalization. Dean Spaeth came from the Department of State and emphasized the international and comparative dimension of law. The Stanford Indian Program (1955-1960) was created under his and professor Lawrence Ebb's leadership (Faculty's interview 10). In the early 1960s, Dean Spaeth sent a young professor, John Merryman, to Europe to prepare himself as a professor of comparative law (Merryman 2007). In the years that followed, Merryman led the Stanford-Chile program (Merryman 2000) and later, together with Lawrence Friedman, the SLADE (Stanford Law and Development) program (Merryman et al. 1979). A group of law and society scholars came to Stanford to work on SLADE. The Law School also hired professor Mauro Cappelletti, a distinguished Italian law professor, who led an ambitious global project on access to justice while at Stanford. Both Merryman and Cappelletti were well-known names in legal scholarship worldwide. The law school also offered courses on the Italian legal system and on Chinese and Soviet law (Pérez Perdomo 2018a).

According to a student who attended Stanford in the 1970s, the law school focus was still mostly national and students expected to become lawyers in American law firms (Alumnus' interview 2). Practically speaking, there were no foreign students and the efforts to internationalize were not considered part of the core program of the school (Faculty interview $3 \& 7$, alumnus interview 2). Master's and doctoral programs existed; but they were disorganized, and attracted only a handful of foreign students.

Under the leadership of Dean Paul Brest and professors Lawrence M. Friedman and Thomas Heller, the school created the Stanford Program in International Legal Studies (SPILS) in 1997 (Faculty interview 7). Later, the School created four other master's degree programs (Corporate governance \& practice; Environmental law \& policy; Law, science \& technology; and International economic law, business and policy). The law school also refurbished the doctoral program (S.J.D.) under the leadership of professor Deborah R. Hensler. The SPILS program leads to a Scientia Juris Master (SJM). The program focuses on interdisciplinary and empirical research and is addressed mainly to foreign law graduates who plan a career in teaching, research, and public policy. It accepts a limited number of fellows (generally twelve) per year. The doctoral program is restricted to those who have gone through the SPILS program and is completely centered on empirical research. The other four masters' degree programs have elements of specialization and also devote some attention to research, but the participants are, on the whole, young lawyers who come out of practice in their country, and will go back into practice at the end of the year (Faculty interview 8). Nevertheless, a number of master's degree graduates stay in the U.S. for further practice or with the idea of establishing there permanently (Alumnus interview 7).

These new programs have produced some change in the nature of the student body. Currently, out of a total student population of about 650 , one in every five students

\footnotetext{
${ }^{10}$ Another faculty member explained to me that this has been a controversial issue and that the faculty is divided. Some prefer a solid, purely legal education for new hires. The collective biography in being developed will show the number of the faculty hired after 1995 who have a Ph.D. degree in another discipline and the number who have only law degrees. This will demonstrate the actual policy and the possible changes over time.
} 
is from another country. Professors have noticed the difference these students make and, on the whole, appreciate that class discussions have become richer (Faculty interviews $4 \& 9$ ). The foreign students do not appear to experience significant cultural shock, and if they have any complaint, it is about the amount of readings expected and the level of demand that participatory discussion sessions with such selective and cosmopolitan groups impose on the students (Alumnus interview $5 \&$ 7).

In addition, the curriculum itself has changed. The so-called "global initiative" involves not only a course in global legal practice and greater integration of comparative law and international issues into existing core courses, but also courses that combine classroom training with intensive overseas study trips - for example, to the International Criminal Court of the Hague. There are also "policy labs", a kind of clinical work in which the students (and the professor) work on a policy issue with real clients. Examples include labs on fake news and misinformation, insurance schemes for autonomous vehicles, judicial selection in California, and rethinking the INTERPOL governance model. There was also a program focused on the production of legal materials, and work on the rule of law on Afghanistan (the ALEP initiative).

Compared with the 1970s, the Stanford Law School of today is a richer and more innovative place with a more international student body. The faculty is more interdisciplinary and the production of scholarship is substantially higher than in the past. Surprisingly, the faculty is if anything a little less international: few professors have studied or done research outside of the United States, worked with a bibliography in languages other than English or published in other languages. Many still have little interest in the world outside the United States, as far as their scholarship is concerned, but the new dean has affirmed that the situation is changing (Dean Martínez, personal conversation, 08-07-19).

Despite this, Stanford Law School, like other leading American law schools, ${ }^{11}$ has become a much more international place. A law school graduate from Latin America or from any civil law country for that matter, would not feel out of place in this environment. In addition to the changes Stanford has undergone, this ease of adaptation is in part due to the fact that the law school's graduates from Latin America and other civil law jurisdictions frequently have had an education quite different than the one described by Damaska and Merryman fifty years ago. A graduate from a modern, good-quality law school in Europe, Asia or Latin America can find the academic environment unusually demanding, but not radically different from that in their country of origin. The next section discusses the interaction of legal education institutions across nations, the transplants and changing perceptions of legal education.

\section{Transplants and globalization}

\subsection{Transplanting legal education}

In the early $19^{\text {th }}$ century, the distinction between common law and civil law countries seemed very clear, and legal education was strikingly different in the two camps. In the civil law countries, lawyers were educated in universities and the profession had only a subsidiary role. In England and the United States, the profession itself was in charge of educating lawyers through apprenticeship. Even a century later, Veblen (1918/2015) claimed that teaching law in a university, was as strange and inappropriate as teaching dance there. He argued that university education might be useful to lawyers as part of a general education, but not for professional education and training.

\footnotetext{
${ }^{11}$ New York University has made a broader effort of globalization, hiring foreign professors and establishing campuses in foreign countries (Davis and Zhang 2018).
} 
In England and the United States, the universities traditionally provided a classical liberal education. English universities might teach Roman and canon law but not English law. Students at Oxford and Cambridge might study the Justinian's Corpus J uris Civilis and they become civil lawyers. Civil lawyers had the privilege of appearing in the Court of Chancery, but they lost that privilege in the $17^{\text {th }}$ century and without it civil lawyers gradually disappeared (Levack 1973, Squibb 1977). Common lawyers, trained by apprenticeship, and who initially were limited to the royal courts, replaced them. In United States, the first law schools were not part of a university but rather the grew from apprenticeships. These institutions are called the "proprietary schools" (Langbein 2004). Instruction in the sciences and education for various professions became a part of universities only in the late $19^{\text {th }}$ century, and this larger movement greatly influenced the development of law school within the universities.

Modern American legal education was a transplant from Germany. Harvard University's President Eliot wanted to redesign Harvard as a place for scientific learning along the lines that he witnessed in Germany. He called upon Christopher Columbus Langdell who put in place what he conceived of as a scientific method for teaching law. Langdell transformed not only the teaching methods but also the organization of the law school: His innovations included the requirement of a previous college degree, three years residence, and blind examinations (Coquillette and Kimball 2015). Harvard became the beacon of American legal education. The transformation process began in 1870 and about 50 years later, the "Harvard model" had become dominant in American legal education (Friedman 2002). In late $20^{\text {th }}$ century, even England accepted the idea of university legal education. This is no longer something that distinguishes the common law from the civil law tradition.

This example suggests that transplants from one legal tradition to another are possible and, in fact, may occur with some frequency. It is true that Harvard-style legal education was in many ways quite different from its German counterpart of the late $19^{\text {th }}$ century and that the gap between them was significant when Rheinstein (1938) compared them in the 1930's. A transplant is not a clone. Adaptions occur because circumstances and resources vary, and that tradition or path dependency has an important weight.

American legal education was far from being a model for other countries during the first part of the $20^{\text {th }}$ century. In the 1930s, European legal education was considered clearly superior. Rheinstein (1938) presented the German model and criticized American legal education as still too close to its professional function. He noted that law professors produced very little scholarship and that legal education was too concentrated on private lawyering, disregarding the much broader social functions of lawyers. Valeur (1928) had similar opinions, but he saw changes coming: the transformation of American law schools into true schools of social sciences, like those in France. In his view, law professors and the scholarly analysis of law were becoming more important for the systematization and unification of American law. Once this occurred, the American legal education would become closer to the French model. Columbia Law School was already heading this way, according to Valeur $(1928,346)$.

In the second part of the $20^{\text {th }}$ century the situation changed, perhaps as a consequence of American leadership in many areas during the post-World War II period. In Latin America there was a conscious effort to learn from the practices of American law schools. Dantas (1955) was probably the first to propose changes for Brazil that were aligned with the modes of legal education that were developing in the United States at that time. He proposed a flexible curriculum, the incorporation of cases, interdisciplinary analysis and the active participation of students. Dantas was a well-recognized jurist, and his proposals stimulated an immediate and broad discussion (Steiner 1971, Bastos 2000, Falcão 2010). In the 1960s, these ideas played an important role in discussions at the five conferences of Latin American law deans, and they were embodied in several recommendations embraced by the deans (Riesco 1976, Wilson 1989, Pérez-Perdomo 2006). 
During that decade, the recently created Federal University of Brasilia's Law School followed these recommendations. The innovations found resistance in many quarters, and when the military took power in Brazil, they disbanded the faculty of Brasilia Law School (Bastos 2000). The new ideas also found fertile ground in the activities of the Chilean Instituto de Investigación y Docencia Jurídica in early 1970, but the Chilean military took power and many of the innovators were fired or forced into exile (Fuenzalida 2003). In Colombia, Peru and Venezuela there were serious skirmishes within the law schools (Lynch 1981, Pérez-Perdomo 2006, 110, Gonzales Mantilla 2008). The main argument for resistance to these innovations was the impossibility or inconvenience of a transplant from a common law country to countries of the civil law tradition. This argument itself was based on a deep ignorance of the history of legal education. For example, lectures became the preferred teaching method in Latin America only late in the $19^{\text {th }}$ century. In Germany, an important civil law country, the problem-case method was in fact traditional (Rheinstein 1938).

In the $21^{\text {st }}$ century, in general terms, the resistance to change has decreased in Latin America mostly because of the creation of new law schools eager to differentiate themselves from the traditional ones. Professors and methods that were shunned in the 1960s were embraced from the 1990s onward in some law schools. Some traditional schools have felt threatened by the competition from new ones and have themselves embarked on important paths of reform. This is one of the reasons why today it is hard to talk of a Latin American (or a civil law) model of legal education as Merryman could still do in 1975. Many Latin American law schools now hire full time professors; they encourage interdisciplinary research and teaching, foster participatory classes and case- or problem-based discussions or put emphasis on the acquisition of professional skills. All these features are the opposite of the characterization of legal education in the civil law tradition which Merryman formulated in 1975.

Nevertheless, legal education in Latin America has kept some distinctive features. One of them, shared with other civil law jurisdictions, is that law is largely undergraduate education. There are specialization, masters and doctoral programs in law, but the number of students in these programs is substantially lower than in the undergraduate programs. Another distinctive feature is the importance of national law. Most law courses emphasize the national law and provide basic information based on this law. This fact is of the utmost importance to understanding the pressures for change. All over the civil law world, economic integration and globalization are putting pressure on legal education to assume a more international and comparative focus (for example: Jamin 2011, 2012, van Caenegem and Hiscock 2014, Cunha and Ghirardi 2018). This situation invites us to consider how legal education is likely to change and to question whether American law schools will soon lose the attraction that they have enjoyed in the last decades for Latin American and European students and scholars.

3.2. Will globalization change legal education and make top American law schools less attractive?

The European Union has brought about major changes in legal education. The integration of national economies, the sway of European law and the power of international law firms have exerted pressure to change the traditional curriculum (van Caenegem and Hiscock 2014, Jamin and van Caenegem 2016). The directives of the European Union to change and harmonize higher education (frequently called "the Bologna process") have put additional pressures on the law schools. European entities, the ministries of education, and the universities' central authorities are pushing for change while many professors and law schools resist (Terry 2006). But changes are happening. The result has been insistence on the importance of critical and analytical tools for working as a professional in a legal setting. Skills such as listening, analyzing, dissecting, negotiating, interviewing, searching for information, writing and presenting a paper, are considered essential (Heringa 2011). More 
participatory classes are considered necessary for developing these skills. The traditional method of magistral classes that provide highly organized information is under heavy criticism and is increasingly replaced or complemented with seminars, clinical education, and simulations. The elegant and masterful class method applauded by Rheinstein (1938) are not praised anymore. Even the well-organized handbooks that became so important in the $20^{\text {th }}$ century are now criticized for providing a distorted vision of law, very far from the messier and more complex legal experience (Jamin 2011, 2012).

In our time, understanding law in its social, economic and business context is considered fundamental. This has led to a new appreciation of courses in comparative law, sociology of law, law and policy, and law and economics (Heringa 2011, 223). These courses, once considered the "soft" part of the law curriculum, are acquiring a new centrality. Furthermore, the most traditional part of legal education, usually presented as a systematization of national law in highly theoretical way, has also changed. Traditional courses like commercial, constitutional or procedural law are being transformed into courses in "comparative civil procedures", "comparative constitutional law", "comparative administrative law" and so on (Heringa and Akkermans 2011). These are the requirements of a transnational integration and a practice of law that has become more international.

The integration among Latin American countries is less complete, but they are part of the globalized world in which we live. In most Latin American law courses, the focus is still national. Skills-oriented courses and activities are more common, but many professors still think that the main task is to organize and transmit wellorganized information about the formal law of the country. Giving this trend, few Latin American law schools attract students from other Latin American countries. Consequently, most students are local, which feeds a kind of parochialism. The faculty is also national, although political and economic upheavals have forced a number of law professors to emigrate and teach in other countries. The first wave consisted of professors leaving Spain in the 1940s and 50s. These professors made an important contribution to Latin American legal scholarship and the diffusion of disciplines like comparative law and philosophy of law. Later, Argentinian, Chilean and Colombian law professors went into exile, mostly to Mexico and Venezuela. The most recent trend is that Venezuelan law professors are migrating to other universities in Latin America and elsewhere. In response to new needs within a changing world, the comparative approach to law has found fertile ground in Latin America, and, in general, emigrated professors have stimulated legal research and reorganization in the law schools. Even in the absence of political upheavals, the tendency to a more international study of law will remain due to the increased internationalization of law and the growing importance of multinational law firms.

The big picture is of a convergence of legal education across national borders and legal traditions. Skills orientation, interdisciplinary education, and an international approach are making powerful inroads everywhere. Some schools are making daring innovations in pursuit of their new notion of excellence in professional training. Physical libraries with grand reading halls are being partially replaced by virtual libraries and smaller meeting rooms permanently connected to the Internet. In this sense technology can serve as an equalizer, but differences among schools do not disappear because new technologies are expensive and many electronic data bases requires superfast broadband connectivity. Nevertheless, the new trends are quite international because communication is now easier.

Do these trends mean that we are moving towards more international, skills-oriented law schools worldwide? If each country develops a certain number of law schools along substantially similar lines, leading international law schools may have diminished attraction for students from other countries. Students may well prefer to study in their own language and close to home. Of course, the future is uncertain. In the world of the 1930s it was unthinkable that American law schools could attain the 
leadership position they have today. It would have seemed particularly unlikely that a small regional school in a sleepy and bucolic corner of the world would attain the preeminence that Stanford Law School has today. But the world changes in unexpected ways. For the moment, American law schools have resources far beyond those available in the more modest and poorer law schools of Europe, Asia, Africa and Latin America. And excellence is frequently linked with a greater investment of resources. But the world is not now and has never been a stable place. The newest trend in the United States is an upsurge of isolationist policies, which is jeopardizing American leadership in the world. It is too soon to know what impact these policies may have on American universities and law schools.

Given these trends, what can we say of the current relevance of Damaska's and Merryman's comparative studies of legal education? These studies tell us a great deal about the situation of legal education, both in the civil law world and the United States, in the 1960s and early 1970s, but we have to read them considering the subsequent transformation of American law schools, the implantation of international law firms in the world and the changes in the legal education offered in Latin America and other continents. These recent developments explain why the culture shock experienced by foreign students in American law schools has been less severe than Damaska expected, but also alert us to the variation in the foreign student's experience depending on factors such as the school receiving the foreign lawyers as students and the background of these lawyers.

The relatively light "trials and tribulations" experienced by foreign lawyers in American law schools explain why so many lawyers from civil law countries have come to the United States. These trends outlined here will likely produce some convergence among legal education systems in the world, but adaptations and changes should call our attention. The comparative studies field has to take in account that legal education, and law, are changing as Heraclitus's river.

\section{References}

Adams, T.E., Holman Jones, S., and Ellis, C., 2015. Autoethnography. New York: Oxford University Press.

Babcock, B., 2013. Reflections on her years at Stanford Law School. Interviewed by C. Mills. Oral History Series. Stanford Law School.

Babcock, B., 2015. Falling into feminism: A personal history. Stanford J ournal of Civil Rights and Civil Liberties, vol. 11, 269.

Ballakrishnen, S., and Silver, C., 2019. A new minority? International J.D. students in U.S. Iaw schools. Law and Social Inquiry [online], 44(3), 647-678. Available from: https://doi.org/10.1017//si.2018.12 [Accessed 2 September 2019].

Bastos, A.W., 2000. O Ensino jurídico no Brasil. $2^{\text {nd }}$ ed. Rio de Janeiro: Lumen J uris.

Campbell, E., 2016. Exploring autoethnography as a method and methodology in legal education research. Asian J ournal of Legal Education [online], 3(1), 95105. Available from: https://doi.org/10.1177/2322005815607141 [Accessed 2 September 2019].

Coquillette, D.R., and Kimball, B.A., 2015. On the Battlefield of Merit: Harvard Law School, the First Century [online]. Cambridge, MA: Harvard University Press. Available from: https://doi.org/10.4159/9780674089068 [Accessed 2 September 2019].

Cunha, L.G., and Ghirardi, J.G., 2018. Legal education in Brazil. The challenges and opportunities of a changing context. In: L.G. Cunha et al., eds., The Brazilian Legal Profession in the Age of Globalization. Cambridge University Press.

Damaska, M., 1968. A continental lawyer in an American law school: Trials and tribulations of adjustment. University of Pennsylvania Law Review [online], 8, 
1363-1378. Available from: https://doi.org/10.2307/3310826 [Accessed 2 September 2019].

Dantas, S., 1955. A educação jurídica e a crise brasileira. Revista Forense, 59.

Davis, K., and Zhang, X., 2018. Who wants the global law school? UC Irvine J ournal of International, transnational, and comparative law [online], 3(1), 73. Available from: https://scholarship.law.uci.edu/ucijil/vol3/issl/4 [Accessed 2 September 2019].

Dezalay, Y., and Garth, B., 2002. The Internationalization of Palace Wars: Lawyers, Economists and the Contest to Transform Latin American States [online]. Chicago University Press. Available from: https://doi.org/10.7208/chicago/9780226144276.001.0001 [Accessed 2 September 2019].

Edwards, G.E., 2011. LL.M. Roadmap: An International Student's Guide to US Law School Programs. New York: Wolters Kluwer.

Falcão, J., 2010. Classe dirigente e ensino jurídico: Uma releitura de SanTiago Dantas. Cadernos FGV Direito [online], vol. 3. Available from: https://bibliotecadigital.fgv.br/dspace/bitstream/handle/10438/10400/Cadern os \% 20FGV\% 20Direito\% 20Rio\% 20$\%$ 20Vol.\%203. pdf? sequence=1\&isAllowed=y [Accessed 2 September 2019].

Friedman, L., 2002. American Law in the $20^{\text {th }}$ Century. New Haven, CT: Yale University Press.

Fuenzalida, E., 2003. Law and legal culture in Chile, 1974-1999. In: L. Friedman and R. Pérez-Perdomo, eds., Legal Culture in the Age of Globalization: Latin America and Latin Europe. Redwood City, CA: Stanford University Press.

Gómez, M., and Pérez-Perdomo, R., 2018. Corporate lawyers and multinational corporations in Latin America and Spain: 1990-2015. In: M. Gómez and R. Pérez-Perdomo, eds., Big Law in Latin America and Spain: Globalization and Adjustments in the Provision of High-End Legal Services [online]. London: Palgrave Macmillan. Available from: https://doi.org/10.1007/978-3-31965403-4_1 [Accessed 2 September 2019].

Gonzales Mantilla, G., 2008. La enseñanza del derecho o los molinos de viento. Cambios, resistencias, continuidades. Lima: Palestra / Pontificia Universidad Católica del Perú.

Gordon, R.W., 1989. Critical legal studies as a teaching method, against the background of the intellectual politics of modern legal education in the United States. Legal Education Review [online], 1(1), 59. Available from: http://classic.austlii.edu.au/au/journals/LegEdRev/1989/6.html [Accessed 2 September 2019].

Gordon, R.W., 2007. The geologic strata of the law school curriculum. Vanderbilt Law Review [online], 60(2), 339-370. Available from: https://digitalcommons. Iaw.yale.edu/fss_papers/1399 [Accessed 2 September 2019].

Hart, H., and Sacks, A., 1958. The Legal Process: Basic Problems on the Making and Application of Law. Tentative edition. Cambridge, MA. (There is a more elaborate edition in 1995, St Paul, West Academic Publishers).

Heringa, A.W., 2011. European legal education or legal education in Europe. Maastricht J ournal of European and Comparative Law [online], 18(3), 221. Available from: https://doi.org/10.1177/1023263X1101800301 [Accessed 2 September 2019]. 
Heringa, A.W., and Akkermans, B., eds., 2011. Educating European Lawyers. Cambridge: Intersentia.

Hufstedler, S., Hufstedler, S., and Christopher, W., 2008. Conversation with Seth and Shirley Hufstedler and Warren Christopher. Interviewed by Sarah Wilson. Oral History Series. Stanford Law School.

Jamin, C., 2011. Le droit des manuels de droit ou l'art de traiter la moitié du sujet. In : A.S. Chambost, ed., Histoire des manuels de droit. Paris : LGDJ .

Jamin, C., 2012. La cuisine du droit. L'École de Droit de Sciences Po: Une expérience française. Paris : LGDJ / Lextenso.

Jamin, C., and van Caenegem, W., eds., 2016. The Internationalisation of Legal Education [online]. Cham: Springer. Available from: https://doi.org/10.1007/978-3-319-29125-3 [Accessed 2 September 2019].

Kennedy, D., 1971. How the law school fails: A polemic. Yale Review of Law and Social Action [online], 1(1), 71-91. Available from: https://digitalcommons. law.yale.edu/yrlsa/vol1/iss1/7 [Accessed 2 September 2019].

Langbein, J.H., 2004. Blackstone, Lichtfield and Yale: the founding of Yale Law School. In: A.T. Kronman, ed., History of the Yale Law School: The Tercentennial Lectures [online]. New Haven, CT: Yale University Press. Available from: https://doi.org/10.12987/yale/9780300095647.003.0003 [Accessed 2 September 2019].

Lazarus-Black, M., 2017. The voice of the stranger: foreign LL.M. students' experience of culture, law and pedagogy in U.S. law schools. In: J.A.R. Nafziger, ed., Comparative Law and Anthropology. Cheltenham: Edward Elgar.

Lazarus-Black, M., and Globokar, J., 2015. Foreign attorneys in U.S. LL.M. programs: Who's in, who's out and who they are. Indiana J ournal of Global Legal Studies [online], 22(1), 3. Available from: https://doi.org/10.2979/indjglolegstu.22.1.3 [Accessed 2 September 2019].

Lempert, D., 2003. After five decades: Stanford Law School class of 1952. Legal Studies Forum [online], vol., 27, 265-275. Available from: https://wwwcdn.law.stanford.edu/wpcontent/uploads/2015/05/by_Lempert_After_Five_Decades_SLS_Class_of 19 52 from 27 Legal_Stud_F 265_2003.pdf [Accessed 2 September 2019].

Levack, B.P., 1973. The Civil Lawyers in England, 1603-1641: A Political Study. Oxford: Clarendon Press.

Lynch, D.O., 1981. Legal Roles in Colombia. Uppsala: Scandinavian Institute for African Studies / New York: International Legal Center.

Manning, B., 2008. Reflections on his Years at Stanford Law School. Interviewed by Sarah Wilson. Oral History Series. Stanford Law School.

McClurg, A.J., 2012. The Companion Text to Law School: Understanding and Surviving Life with a Law Student. St Paul, MN: West Academic.

McClurg, A.J., 2017. 1L on a Ride: A Well-Traveled Professor's Roadmap to Success in the First-Year Law School. $3^{\text {rd }}$ ed. St Paul, MN: West Academic.

Méndez Longoria, M.A., 2008. Innovación pedagógica temprana en la Escuela de Derecho de Stanford. Cuadernos Unimetanos [online], 15, 108. Available from: https://law.stanford.edu/publications/innovacion-pedagogica-tempranaen-la-escuela-de-derecho-de-stanford/ [Accessed 2 September 2019].

Méndez, M., 2009. On Stanford Law School: Conversation with Michael Wald and Fred Álvarez. Oral History Series. Stanford Law School. 
Merryman, J.H., 1974. Legal education there and here. A comparison. Stanford Law Review [online], 27(3), 859-878. Available from:

https://doi.org/10.2307/1228342 [Accessed 2 September 2019].

Merryman, J.H., 2000. Law and development memoirs I: The Chile law program. American J ournal of Comparative Law [online], 48(3). Available from: https://doi.org/10.2307/840862 [Accessed 2 September 2019].

Merryman, J.H., 2007. John Henry Merryman: Reflections on his Years at Stanford Law School. Interviewed by Barbara Babcock and Lawrence Friedman. Oral History Series. Stanford Law School.

Merryman, J.H., and Pérez-Perdomo, R., 2019. The Civil Law Tradition. $4^{\text {th }}$ ed. Redwood City, CA: Stanford University Press.

Merryman, J.H., Clark, D.S., and Friedman, L.M., eds., 1979. Law and Social Change in Mediterranean Europe and Latin America: A Handbook of Legal and Social Indicators for Comparative Law Study. Stanford Law School / New York: Dobbs Ferry.

Mertz, E., 2007. The Language of the Law School: Learning to "Think like a Lawyer". Oxford University Press.

Osborn, J.J., 1971. The Paper Chase. Boston, MA: Houghton Mifflin.

Pérez Hurtado, L.F., 2009. La futura generación de abogados mexicanos: Estudio de las escuelas y los estudiantes de derecho en México. Ciudad de México: Universidad Nacional Autónoma de México.

Pérez Perdomo, R., 2018a. De Harvard a Stanford: Sobre la historia de la educación jurídica en los Estados Unidos. Boletín Mexicano de Derecho Comparado [online], 151, 313. Available from: http://www. scielo.org. mx/pdf/bmdc/v51n151/2448-4873-bmdc-51-151313.pdf [Accessed 2 September 2019].

Pérez Perdomo, R., 2018b. Educación jurídica y política en Venezuela revolucionaria. In: G. Gonzales Mantilla, ed.: La educación legal como política pública en América Latina. Lima: Palestra.

Pérez-Perdomo, R., 2006. Latin American Lawyers: A Historical Introduction [online]. Redwood City, CA: Stanford University Press. Available from: https://doi.org/10.11126/stanford/9780804751261.001.0001 [Accessed 2 September 2019].

Rheinstein, M., 1938. Law faculties and law schools. A comparison of legal education of legal education in the United States and Germany. Wisconsin Law Review [online], 5. Available from:

https: //chicagounbound.uchicago.edu/cgi/viewcontent.cgi?article $=13117 \&$ cont ext=journal_articles [Accessed 2 September 2019].

Riesco, J.A., 1976. Conclusiones de la $V$ conferencia de facultades y escuelas de derecho de América Latina. Informe del relator general. In: J. Witker, ed., Antología de estudios sobre la enseñanza del derecho. Ciudad de México: Universidad Nacional Autónoma de México.

Silver, C., 2012. States side story: Career paths of international LL. M. students. Fordham Law School Review [online], 80(6), 2383. Available from: http://ir.lawnet.fordham.edu/flr/vol80/iss6/4 [Accessed 2 September 2019].

Silver, C., and Ballakrishnen, S.S., 2018. Sticky floors, springboards, stairways \& slow scalators: Mobility pathways and preferences of international students in U.S. Iaw schools. UC Irvine J ournal of International, Transnational, and Comparative Law [online], 3(1), 39. Available from: 
https://scholarship.law.uci.edu/ucijil/vol3/iss1/3 [Accessed 2 September 2019].

Squibb, G.D., 1977. Doctors' Commons: A History of the College of Advocates and Doctors of Law. Oxford: Clarendon Press.

Steiner, H., 1971. Legal education and socio-economic change: Brazilian perspectives. American J ournal of Comparative Law [online], 19(1). Available from: https://doi.org/10.2307/839148 [Accessed 2 September 2019].

Stevens, R., 1983. Law School: Legal Education in America from 1850s to the 1980s. Chapel Hill: The University of North Carolina Press.

Terry, L.S., 2006. Living with the Bologna process: Recommendations to the German Legal Education Community from a U.S. Perspective. German Law Journal [online], 7(11). Available from: https://doi.org/10.1017/S2071832200005186 [Accessed 2 September 2019].

Trubek, D., and Galanter, M., 1974. Scholars in self-estrangement: Some reflections on the crisis in law and development studies in the United States. Wisconsin Law Review, no 4, 1062.

Turow, S., 1977. One L. New York: Putnam.

Valeur, R., 1928. L'enseignement du droit en France et aux États-Unis. Paris : Marcel Giard.

van Caenegem, W., and Hiscock, M., eds., 2014. The Internationalisation of Legal Education: The Future Practice of Law [online]. Cheltenham: Edward Elgar. Available from: https://doi.org/10.4337/9781783474547 [Accessed 2 September 2019].

Veblen, T. (with Richard F. Teichgraeber III, edition and notes), 2015. The Higher Learning in America: A Memorandum on the Conduct of Universities by Business Men. Baltimore, MD: J ohns Hopkins University Press. (Originally published in 1918).

Vides, M., Gómez, M., and Pérez Hurtado, L.F., 2011. The American way: Los abogados latinoamericanos como estudiantes de maestría en Estados Unidos de América. Boletín Mexicano de Derecho Comparado [online], 44(130), 351399. Available from:

http://www.scielo.org. mx/scielo.php?script=sci_arttext\&pid=S004186332011000100011 [Accessed 2 September 2019].

Wall, S.S., 2016. Toward a moderate autoethnography. International J ournal of Qualitative Research [online], 15, 1. Available from: https://doi.org/10.1177/1609406916674966 [Accessed 2 September 2019].

Wilson, R., 1989. The new legal education in North and South America. Stanford J ournal of International Law, 25, 375.

Young, K.M., 2018. How to Be Sort of Happy in Law School. Redwood City, CA: Stanford University Press. 